\title{
PENGARUH DEBT TO EQUITY RATIO (DER) DAN DEBT TO ASSET RATIO (DAR) TERHADAP KINERJA PERUSAHAAN DI SEKTOR KEUANGAN YANG TERDAFTAR DI BURSA EFEK INDONESIA
}

\author{
Azzalia Feronicha Wianta Efendi ${ }^{1)}$, Seto Sulaksono Adi Wibowo ${ }^{2)}$ \\ 1) Jurusan Manajemen Bisnis, Politeknik Negeri Batam, Batam 29461, email: azzalia.feronicha@yahoo.co.id \\ 2) Jurusan Manajemen Bisnis, Politeknik Negeri Batam, Batam 29461, email: $\underline{\text { seto@ polibatam.ac.id }}$
}

\begin{abstract}
Abstrak - Perbandingan antara modal sendiri dan modal asing yang tersusun dalam struktur modal menjadi instrumen yang digunakan perusahaan untuk merencanakan dan mengambil kebijakan penggunaan hutang dalam memaksimalkan keuntungan dan harga saham perusahaan. Perbankan dalam melakukan kegiatan operasionalnya harus memiliki modal yang cukup besar dan terstruktur dengan baik, agar terhindar dari permasalahan keuangan. Untuk menarik penanam modal, perbankan didesak untuk menaikkan kinerjanya yang dapat dinilai dari laporan keuangan bank dalam memberikan informasi bagi investor. Penelitian ini bertujuan untuk mengetahui pengaruh secara parsial struktur modal yang diproksikan dengan rasio leverage yaitu Debt to Equity Ratio (DER) dan Debt to Asset Ratio (DAR) terhadap kinerja perusahaan yang dilihat dari profitabilitasnya dengan Return on Asset (ROA) dan Return on Equity (ROE) perusahaan perbankan selama 3 tahun. Penelitian ini menggunakan sampel 30 bank selama 3 tahun dari 2013-2015 dengan menggunakan analisis regresi data panel. Hasil penelitian menunjukkan secara parsial variabel DER berpengaruh terhadap ROA dan ROE, serta secara parsial variabel DAR berpengaruh terhadap ROA dan tidak berpengaruh terhadap ROE. Penelitian ini terbatas hanya dilakukan pada perusahaan perbankan saja dan dalam kurun waktu 3 tahun, seharusnya dapat menggunakan sektor perusahaan lainnya dan kurun waktu yang lebih lama. Penelitian selanjutnya diharapkan dapat menambah variabel penelitian, sektor perusahaan, sampel dan menambah periode penelitian.
\end{abstract}

Kata Kunci: Struktur Modal, Perbankan, Kinerja Perusahaan, leverage, Debt to Equity Ratio (DER), Debt to Asset Ratio (DAR), Return on Asset (ROA), Return on Equity (ROE).

\begin{abstract}
Comparison between self-capital and foreign capital structured in capital structure into an instrument used by companies to plan and take debt usage policies in maximizing profits and stock prices company. Banking in conducting its operational activities must have a large enough capital and well structured, in order to avoid the financial problems. To attract investors, banks are urged to improve their performance that can be assessed from bank financial statements in providing information to investors. This study aims to determine the partial influence of capital structure proxyed with leverage ratios those are Debt to Equity Ratio (DER) and Debt to Asset Ratio (DAR) to company performance seen from its profitability with Return on Asset (ROA) and Return on Equity (ROE) of banking companies for 3 years. This study used a sample of 30 banks for 3 years from 2013-2015 by using panel data regression analysis. The results showed partially DER variables affect the ROA and ROE, and partially DAR variables affect the ROA and no effect on ROE. This study is limited to a banking company only and within 3 years, it should be able to use other corporate sectors and longer periods of time. Further research is expected to add research variables, corporate sectors, samples and add to the studyperiod.
\end{abstract}

Keywords: Capital Structure, Banking, Corporate Performance, Leverage, Debt to Equity Ratio (DER), Debt to Asset Ratio (DAR), Return on Assets (ROA), Return on Equity (ROE). 


\section{Pendahuluan}

Pergerakan ekonomi dunia sangat dinamis di era globalisasi yang berkembang sangat cepat saat ini, dimana arus teknologi dan informasi serta transportasi berkembang pesat termasuk pertumbuhan dan perkembangan dunia usaha. Untuk menghadapi persaingan, perusahaan di luar maupun dalam negeri harus bertumbuh dan berkembang secara berkesinambungan untuk mendapatkan kepercayaan para investor. Variabel yang sangat penting dalam kemajuan dan menjaga presensi perusahaan adalah modal. Manajemen perusahaan senantiasa dihadapkan pada keputusan untuk menentukan komposisi struktur modal antara modal internal dan eksternal (Komara et al, 2014).

Perusahaan-perusahaan yang objektif akan berusaha dalam menentukan struktur modal secara ideal dan menambah modal baru sesuai target dengan tetap menjaga keselarasan struktur modal perusahaan, termasuk perbankan. Aktivitas untuk mendeteksi perubahan dalam tren pengembangan perusahaan perbankan dalam membuat keputusan ekonomi yang berhasil, yakni perlu dilakukan analisis laporan keuangan bank yaitu proses menganalisis dan mengkaji neraca perusahaan (statement of financial position), laporan laba rugi (income statement), dan pernyataan lainnya.

Penelitian Dawar (2014) yang meneliti pengaruh struktur modal terhadap kinerja perusahaan yang terdaftar di Bursa Efek Bombay dengan variabel dependen yang digunakan merupakan kinerja perusahaan yang diukur dengan rasio profitabilitas (ROA \& ROE), variabel inependennya merupakan struktur modal yang diproksikan dengan dengan leverage (STD \& LTD) dan variabel kontrol menggunakan firm size, firm age, tangibility, sales growth, liquidity dan advertising. Hasil penelitian Dawar (2014) menunjukkan struktur modal berpengaruh negatif terhadap kinerja perusahaan. Semua variabel kontrol berpengaruh positif terhadap kinerja perusahaan kecuali firm age.

Penelitian mengenai pengaruh struktur modal terhadap kinerja perusahaan telah banyak dilakukan di Indonesia dan berbagai negara. Namun demikian, penelitian-penelitian yang dilakukan menunjukkan hasil yang berbeda-beda di tiap negara dan juga terdapat dinamika rasio- rasio keuangan yang tidak menentu. Perkembangan kinerja keuangan perbankan juga akan mengalami fluktuasi tiap periodenya dan sektor perbankan yang terdaftar di BEI dapat menjadi pilihan investasi bagi investor karena perkembangan kinerja keuangannya, dengan begitu aktivitas bank sangat penting dan diperlukan demi kelancaran kegiatan perekonomian Indonesia di bidang riil. Peneliti tertarik untuk mengembangkan penelitian Dawar (2014) di Indonesia dalam sektor yang berbeda yaitu sektor keuangan sub sektor perbankan, karena Dawar (2014) mengambil sampel penelitiannya berupa perusahaan yang terdaftar di Bombay Stock Exchange (BSE) kecuali bank dan perusahaan keuangan non bank lainnya. Peneliti ingin mengetahui dan mengekplorasi lebih dalam apa dampak sebenarnya yang hadir dari struktur modal terhadap kinerja perusahaan di sektor yang berbeda.

\section{Kajian teori dan literatur}

\section{Agency Theory}

Teori agensi dikemukakan oleh Jensen dan Meckling pada tahun 1976 yang mendeskripsikan hubungan antara pemegang saham sebagai prinsipal dan manajemen sebagai agen. Manajemen merupakan pihak yang dikontrak oleh pemegang saham untuk bekerja demi kepentingan pemegang saham. Hubungan keagenan merupakan suatu kontrak dimana satu atau lebih orang (prinsipal) memerintah orang lain (agen) untuk melakukan suatu jasa atas nama prinsipal serta memberi wewenang kepada agen membuat keputusan yang terbaik bagi prinsipal. Dengan proporsi kepemilikan yang hanya sebagian dari perusahaan membuat manajer cenderung bertindak untuk kepentingan pribadi dan bukan untuk memaksimalkan kepentingan perusahaan. Hal inilah yang akan menyebabkan masalah keagenan sehingga nantinya akan menimbulkan biaya keagenean (agency cost). Jensen dan Meckling (1976) mendefinisikan biaya keagenan sebagai jumlah dari biaya yang dikeluarkan prinsipal untuk melakukan pengawasan terhadap agen.

\section{Trade Off Theory}

Teori trade off merupakan gagasan bahwa perusahaan memilih berapa banyak pembiayaan hutang dan berapa banyak dana ekuitas yang 
digunakan dengan menyeimbangkan biaya dan manfaat. Tujuan penting dari teori ini adalah untuk menjelaskan fakta bahwa perusahaan biasanya dibiayai sebagian dengan hutang dan sebagian lagi dengan ekuitas. Perusahaan mendasarkan keputusan pendanaan pada struktur modal yang optimal. Struktur modal yang optimal dibentuk dengan menyeimbangkan manfaat dari penghematan pajak atas penggunaan hutang terhadap biaya kebangkrutan.

\section{Pecking Order Theory}

Teori pecking order mengasumsikan bahwa perusahaan bertujuan untuk memaksimumkan kesejahteraan pemegang saham. Dalam corporate finance, teori pecking order mendalilkan bahwa biaya pembiayaan meningkat dengan informasi asimetris. Pembiayaan berasal dari tiga sumber yaitu dana internal, hutang dan ekuitas baru. Perusahaan memprioritaskan sumber pembiayaan mereka, pertama memilih pembiayaan internal, kemudian hutang dan terakhir meningkatkan ekuitas sebagai upaya terakhir. Teori pecking order dipopulerkan oleh Myers dan Majluf (1984) dimana mereka berpendapat bahwa ekuitas adalah cara yang kurang disukai untuk meningkatkan modal karena ketika para manajer (yang diasumsikan lebih tahu tentang kondisi sebenarnya dari firma daripada investor), hal ini menjadi masalah.

Sugihen (2003) melakukan penelitian dengan menganalisis dan menguji pengaruh langsung dan pengaruh tidak langsung antara struktur modal dengan produktivitas aktiva, kinerja keuangan, dan nilai perusahaan dari perusahaan industri manufaktur terbuka Indonesia yang terdftar di Bursa Efek Jakarta pada tahun 19952000. Penelitian tersebut menemukan bahwa struktur modal berpengaruh terhadap aktivitas operasi, kinerja keuangan, dan nilai perusahaan. Temuan penelitian Sugihen (2003) mengindikasikan bahwa peningkatan hutang pada struktur modal tidak menyebabkan pertambahan investasi, sehingga perubahan struktur modal tidak berpengaruh terhadap aktivitas investasi dan produktivitas aktiva.
Rachmawardani (2007) meneliti tentang analisis pengaruh aspek likuiditas, risiko bisnis, profitabilitas, dan pertumbuhan penjualan terhadap struktur modal perusahaan dengan sampel perusahaan perbankan yang terdaftar di Bursa Efek Jakarta tahun 2000-2005. Struktur modal dalam penelitian diproksikan dengan Debt to Equity Ratio (DER) yang dilakukan pengujian dengan aspek likuiditas, risiko bisnis, profitabilitas, dan pertumbuhan penjualan. Dari hasil penelitian ini diketahui bahwa faktor-faktor seperti risiko bisnis dan profitabilitas berpengaruh secara signifikan terhadap struktur modal. Hal ini menyiratkan bahwa variabelvariabel tersebut merupakan variabel yang dapat dikendalikan oleh perusahaan.

\section{Hipotesis}

ROA merupakan indikator kinerja bank umum secara umum, karena menunjukkan hubungan antara earnings dan asset serta ROA dapat diukur secara keseluruhan earnings bank per satuan unit moneter aset dan juga dapat digunakan untuk membandingkan kinerja bank umum dalam industri perbankan (Zimmerman, 1996). Menurut Kusumajaya (2011) bagi setiap perusahaan, keputusan dalam pemilihan sumber dana merupakan hal penting sebab hal tersebut akan mempengaruhi struktur keuangan perusahaan yang akhirnya akan mempengaruhi profitabilitas. Sumber dana perusahaan dicerminkan oleh modal asing dan modal sendiri yang diukur dengan Debt to Equity Ratio (DER). Jika DER semakin tinggi, maka kemampuan perusahaan untuk mendapatkan profitabilitas akan semakin rendah, sehingga DER mempunyai hubungan negatif dengan profitabilitas.

\section{H1: DER dan DAR berpengaruh terhadap Return on Asset (ROA).}

Return on Equity (ROE) merupakan rasio yang menunjukkan kemampuan perusahaan dalam menghasilkan laba bersih untuk pengembalian ekuitas pemegang saham dan ROE merupakan rasio keuangan yang digunakan untuk mengukur profitabilitas dari ekuitas (Kusumajaya, 2011). ROE bisa menjadi patokan efisiensi penggunaan modal internal yang dioperasionalkan dalam 
perusahaan perbankan. Semakin besar nilai ROE, semakin besar juga kapabilitas bank menghasilkan laba bagi investor. Penelitian yang dilakukan Maryono (2014) juga menyatakan struktur modal berpengaruh signifikan terhadap ROE perusahaan perbankan.

\section{H2 : DER dan DAR berpengaruh terhadap} Return of Equity (ROE).

\section{Metode Penelitian}

\section{Sampel}

Populasi dalam penelitian ini adalah sebanyak 30 perusahaan sektor keuangan sub sektor perbankan yang terdaftar di Bursa Efek Indonesia (BEI) tahun 2013-2015.

\section{Variabel}

Variabel yang digunakan dalam penelitian ini adalah independen dan dependen. Variabel independen dalam penelitian ini adalah Debt to Equity Ratio (DER) dan Debt to Asset Ratio (DAR). Terdapat dua variabel dependen yang akan digunakan dalam penelitian ini yaitu Return on Asset (ROA) dan Return on Equity (ROE).

\section{Hasil Dan Pembahasan}

\section{Analisis Statistik Deskriptif}

Hasil uji statistik menggunakan Eviews 9 berikut menghasilkan output yang menggambarkan hasil mean, maximum, minimum dan standard deviation dari variabel dependen dan independen, sehingga dapat dilihat secara statistik bagaimana deskripsi dari variabel tersebut. Debt to Equity Ratio (DER) memiliki nilai mean sebesar 8.212208 yang berarti bahwa rata-rata hutang perusahaan jika dibandingkan dengan ekuitas memiliki risiko sebesar 8.212208 terhadap likuiditas perusahaan. Nilai paling tinggi untuk hutang perusahaan jika dibandingkan dengan ekuitas memiliki risiko sebesar 70.00785 terhadap likuiditas perusahaan dan yang paling rendah sebesar 0.047543. Debt to Asset Ratio (DAR) memiliki nilai mean sebesar 0.93836 yang berarti bahwa rata-rata hutang perusahaan relatif terhadap aset memiliki risiko sebesar 0.93836 terhadap likuiditas perusahaan. Nilai paling tinggi untuk hutang perusahaan relatif terhadap aset memiliki risiko sebesar 8.750122 dan yang paling rendah sebesar 0.047543 .

Return on Asset (ROA) memiliki nilai mean sebesar 0.015705 yang berarti bahwa rata-rata kemampuan perusahaan dalam memanfaatkan aset untuk menghasilkan profitabilitas perusahaan adalah sebesar 0.015705. Nilai paling tinggi bagi kemampuan perusahaan dalam memanfaatkan aset untuk menghasilkan profitabilitas adalah sebesar 0.05298 dan yang paling rendah adalah sebesar -0.07633 . Return on Equity (ROE) memiliki nilai mean sebesar 0.061705 yang berarti bahwa rata-rata kemampuan perusahaan dalam memanfaatkan investasi pemegang sahamnya untuk menghasilkan profitabilitas perusahaan adalah sebesar 0.061705. Nilai paling tinggi yaitu 0.268357 dan yang paling rendah yaitu 1.065951 .

\section{Analisis Regresi Data Panel}

Regresi data panel merupakan gabungan antara data cross section dan data time series, dimana unit cross section yang sama diukur pada waktu yang berbeda. Penggunaan data panel dalam regresi akan menghasilkan intersep dan slope. Variabel-variabel independen secara spesifik terhadap variabel dependen dalam penelitian ini yang diuji dinyatakan dalam persamaan regresi di bawah ini:

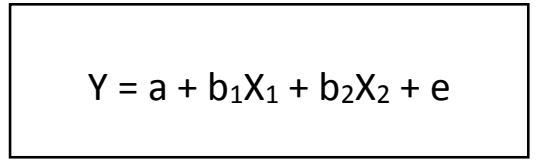

Sumber : (Mahardian, 2008)

Dimana:

$$
\begin{aligned}
& \mathrm{Y}=\text { variabel dependen }(\mathrm{ROA} / \mathrm{ROE}) \\
& \mathrm{a}=\text { konstantsa } \\
& \mathrm{X}_{1}=\text { variabel independen }(\mathrm{DER}) \\
& \mathrm{X}_{2}=\text { variabel independen (DAR) } \\
& \mathrm{b}_{1} \ldots, \mathrm{b}_{\mathrm{n}}=\text { koefisien regresi } \\
& \mathrm{e}=\text { error term }
\end{aligned}
$$




\section{Model Regresi Hipotesis 1}

\begin{tabular}{|c|c|c|c|c|}
\hline \multicolumn{5}{|c|}{$\begin{array}{l}\text { Dependent Variable: ROA } \\
\text { Method Panel Least Squares } \\
\text { Date: 06/05/17 Time: 06:35 } \\
\text { Sample: } 20132015 \\
\text { Periods included. } 3 \\
\text { Cross-sections included: } 30 \\
\text { Total panel (balanced) observations: } 90\end{array}$} \\
\hline Variable & Coefficient & Std. Error & t. Statistic & Prob. \\
\hline $\begin{array}{l}\text { C } \\
\text { DER } \\
\text { DAR }\end{array}$ & $\begin{array}{r}0.017755 \\
-0.001852 \\
0.014022\end{array}$ & $\begin{array}{l}0.002667 \\
0.000710 \\
0.006056\end{array}$ & $\begin{array}{r}6.657273 \\
-2.609110 \\
2.315512\end{array}$ & $\begin{array}{l}0.0000 \\
0.0107 \\
0.0229\end{array}$ \\
\hline $\begin{array}{l}\text { R-squared } \\
\text { AdjustedR-squared } \\
\text { S.E. of regression } \\
\text { Sumsquaredresid } \\
\text { Loglikelihood } \\
\text { F-statistic } \\
\text { Prob(F-statistic) }\end{array}$ & $\begin{array}{l}0.074071 \\
0.052785 \\
0.016557 \\
0.023851 \\
242.9044 \\
3.479849 \\
0.035166\end{array}$ & $\begin{array}{l}\text { Mean depend } \\
\text { S.D depende } \\
\text { Akaike info er } \\
\text { Schwarz crite } \\
\text { Hannan-Quin } \\
\text { Durbin-Watso }\end{array}$ & $\begin{array}{l}\text { Itvar } \\
\text { var } \\
\text { rion } \\
\text { niter. } \\
\text { citat }\end{array}$ & $\begin{array}{r}0.015705 \\
0.017012 \\
-5.331208 \\
-5.247081 \\
-5.297606 \\
1.563899\end{array}$ \\
\hline
\end{tabular}

Sumber: Data sekunder diolah, Eviews 9 (2017),

Berdasarkan tabel 4.5 diatas, maka dapat dibuat model regresi dengan persamaan berikut:

$$
\begin{gathered}
\mathrm{Y}=\mathrm{a}+\mathrm{b}_{1} \mathrm{DER}+\mathrm{b}_{2} \mathrm{DAR}+\mathrm{e} \\
\mathrm{ROA}=0.0177-0.0018 \mathrm{DER}+0.014 \mathrm{DAR}+\mathrm{e}
\end{gathered}
$$

1) Nilai konstanta sebesar 0.0177 menjelaskan bahwa apabila variabel independen dianggap konstan atau nol makan nilai dari ROA sebesar 0.0177 .

2) Koefisien regresi Debt to Equity Ratio (DER) sebesar -0.0018 menjelaskan bahwa apabila DER meningkat satu satuan dan variabel independen lainnya dianggap tetap, maka akan diikuti dengan penurunan kinerja perusahaan yang diproksikan dengan ROA sebesar 0.0018 .

3) Koefisien regresi Debt to Asset Ratio (DAR) sebesar 0.014 menjelaskan bahwa apabila DAR meningkat satu satuan dan variabel independen lainnya dianggap tetap maka akan diikuti dengan peningkatan kinerja perusahaan yang diproksikan dengan ROA sebesar 0.014 .

\section{Model Regresi Hipotesis 2}

\begin{tabular}{|c|c|c|c|c|}
\hline \multicolumn{5}{|c|}{$\begin{array}{l}\text { Dependent Variable: ROE } \\
\text { Method: Panel EGLS (Cross-section random effects) } \\
\text { Dste: } 06 / 05 / 17 \text { Time: } 07: 07 \\
\text { Sample: } 20132015 \\
\text { Periods included: } 3 \\
\text { Cross-5ections included: } 30 \\
\text { Total psanel (bslanced) observations: } 90 \\
\text { Swamy and Arors estimstor of component variances }\end{array}$} \\
\hline Variable & Coefficient & Std. Error & $t-$ Statistic & Prob. \\
\hline c & 0.073392 & 0.033437 & 2.194967 & 0.0308 \\
\hline DER & -0.021682 & 0.007265 & -2.984573 & 0.0037 \\
\hline DAR & 0.177297 & 0.061629 & 2.876858 & 0.0051 \\
\hline \multicolumn{5}{|c|}{ Effects Specification } \\
\hline & & & & \\
\hline $\begin{array}{l}\text { Cross-section random } \\
\text { Idiosyncratic random }\end{array}$ & & & $\begin{array}{l}0.138529 \\
0.123544\end{array}$ & $\begin{array}{l}0.5570 \\
0.4430\end{array}$ \\
\hline \multicolumn{5}{|c|}{ Weighted Statistics } \\
\hline R-squared & 0.089270 & \multirow{5}{*}{\multicolumn{2}{|c|}{$\begin{array}{l}\text { Mesn dependent var } \\
\text { S.D. dependent var } \\
\text { Sum squared resid } \\
\text { Durbin-Watson stat }\end{array}$}} & 0.028247 \\
\hline Adjusted R-squared & 0.068334 & & & 0.130865 \\
\hline S.E. of regression & 0.126314 & & & 1.388113 \\
\hline F-statistic & 4.263906 & & & 1.243300 \\
\hline Prob(F-statistic) & 0.017117 & & & \\
\hline \multicolumn{5}{|c|}{ Unweighted Statistics } \\
\hline R-squared & 0.158003 & \multirow{2}{*}{\multicolumn{2}{|c|}{$\begin{array}{l}\text { Mesn dependent var } \\
\text { Durbin-Watson stat }\end{array}$}} & 0.061705 \\
\hline Sum squared resid & 3.208010 & & & 0.537979 \\
\hline
\end{tabular}

Tabel 4.9 Hasil Persamaan Regresi ROE

Berdasarkan tabel 4.9 di atas, maka dapat dibuat model regresi dengan persamaan berikut:

$$
\begin{gathered}
\mathrm{Y}=\mathrm{a}+\mathrm{b}_{1} \mathrm{DER}+\mathrm{b}_{2} \mathrm{DAR}+\mathrm{e} \\
\mathrm{ROE}=0.0733-0.0216 \mathrm{DER}+0.0772 \mathrm{DAR}+\mathrm{e}
\end{gathered}
$$

1) Nilai konstanta sebesar 0.0733 menjelaskan bahwa apabila variabel independen dianggap konstan atau nol maka nilai dari $\mathrm{ROE}$ sebesar 0.0733 .

2) Koefisien regresi Debt to Equity Ratio (DER) sebesar -0.0216 menjelaskan bahwa apabila DER meningkat satu satuan dan variabel independen lainnya dianggap tetap, maka akan diikuti dengan penurunan kinerja perusahaan yang diproksikan dengan ROE sebesar 0.0216 .

3) Koefisien regresi Debt to Asset Ratio (DAR) sebesar 0.1772 menjelaskan bahwa apabila DAR meningkat satu satuan dan variabel independen lainnya dianggap tetap maka akan diikuti dengan peningkatan kinerja perusahaan yang diproksikan dengan ROE sebesar 0.1772 . 


\section{Analisis Data Pengaruh DER dan DAR terhadap ROA}

Penelitian ini menunjukkan bahwa DER berpengaruh terhadap ROA. Hal ini terbukti dengan ditunjukkannya pengaruh negatif dan signifikan dimana nilai $\mathrm{t}=-2.6091$ dan $\mathrm{p}=$ 0.0107 ( $\mathrm{p}<0.05)$. DAR juga berpengaruh terhadap ROA, hal ini terbukti dengan ditunjukkannya pengaruh positif dan signifikan dimana $t=2.3155$ dan $\mathrm{p}=0.022(\mathrm{p}<0.05)$.

\section{Pengaruh DER dan DAR terhadap ROE}

Penelitian ini menunjukkan bahwa DER berpengaruh terhadap ROE. Hal ini terbukti dengan ditunjukkannya pengaruh negatif dan signifikan dimana nilai $\mathrm{t}=-2.9845$ dan $\mathrm{p}=$ $0.0037(\mathrm{p}<0.05)$. DAR tidak berpengaruh terhadap ROE, hal ini terbukti dengan ditunjukkannya pengaruh positif dan tidak signifikan dimana $\mathrm{t}=2.3155$ dan $\mathrm{p}=0.051$ $(p>0.05)$.

\section{Kesimpulan}

Berdasarkan hasil penelitian dan pembahasan mengenai pengaruh DER dan DAR terhadap kinerja perusahaan sektor keuangan sub sektor perbankan yang terdaftar di Bursa Efek Indonesia periode 2013-2015, maka penulis memperoleh beberapa kesimpulan sebagai berikut:

1)Pengujian secara parsial variabel bebas DER terhadap variabel terikat ROA berpengaruh, sehingga $\mathrm{H} 1$ diterima. Pengujian secara parsial variabel bebas DER terhadap ROE juga berpengaruh, sehingga $\mathrm{H} 2$ diterima. 2)Pengujian secara parsial variabel bebas DAR terhadap variabel terikat ROA berpengaruh, sehingga $\mathrm{H} 1$ diterima. Pengujian secara parsial variabel bebas DAR terhadap ROE tidak berpengaruh, sehingga H2 ditolak.

\section{Keterbatasan}

Penelitian ini terdapat beberapa keterbatasan, antara lain: 1) sampel penelitian yang digunakan hanya terbatas pada perusahaan sektor keuangan sub sektor perbankan saja. 2) Penelitian ini hanya menggunakan dua variabel independen dari sisi leverage saja, padahal banyak variabel lain yang kemungkinan besar dapat menunjukkan tingkat risiko hutang perusahaan untuk memproksikan struktur modal terhadap profitabilitas perusahaan. 3) Hasil dari pengujian dengan kecocokan model yang dipilih penulis sangat rendah, sehingga kemampuan variabelvariabel independen menjelaskan variabel dependen dalam penelitian ini amat terbatas.

\section{Saran}

Saran untuk penelitian selanjutnya sebaiknya meningkatkan atau menambah jumlah sampel perusahaan, menambah periode penelitian, dan tidak terbatas hanya pada 1 sektor di Bursa Efek Indonesia saja sehingga diperoleh hasil penelitian yang lebih baik. Variabel penelitian independen dan dependen lain juga dapat diteliti untuk mengetahui pengaruhnya, serta dapat menggunakan proksi yang berbeda untuk mengukur tingkat rasio pada variabel. Pertumbuhan ekonomi, suku bunga BI, tingkat inflasi, dan nilai tukar dapat ditambahkan dalam variabel independen untuk hasil yang lebih baik dan mencerminkan kondisi aktual perbankan di Indonesia. Kriteria pemilihan model juga harus diperhatikan dalam pengujian masa depan.

\section{Daftar Referensi}

Dawar, V. (2014). Agency theory, capital structure and firm performance: Some Indian evidence. Managerial Finance, 40 (12).

Fahmi, I. (2011). Analisis Kinerja Keuangan. Bandung: Alfabeta.

Ghozali, I. (2006). Aplikasi Analisis Multivariate dengan SPSS (Cetakan Keempat ed.). Semarang: Badan Penerbit Universitas Diponegoro.

Ghozali, I. (2009). Aplikasi Analisis Multivariate dengan SPSS (Edisi Keempat ed.). Semarang: Badan Penerbit Universitas Diponegoro. 
Goyal, A. (2013). Impact of Capital Structure on Performance of Listed Public Sector Banks in India. International Journal of Business and Management Invention , 2 (10), 35-43.

Hailu, A. (2015). The Impact of Capital Structure on Profitability of Commercial Banks in Ethiopia. Accounting and Finance .

Isnarno, E. (2012). Analisis Pengarug Current Ratio (CR), Debt to Equity Ratio (DER), Total Asset Turnover (TAT), dan Size Terhadap Return on Equity (ROE) dengan Institutional Ownership (Instown) Sebagai Variabel Moderating Pengaruh DER Terhadap ROE .

Jensen, M. (1976). Theory of The Firm: Managerial Behavior, Agency Costs and Ownership Stucture. Journal of Financial Economics.

Komara, H. A. (2014). Analisis Pengaruh Struktur Modal Terhadap Kinerja Keuangan Perusahaan. Jurnal Keuangan dan Perbankan , 20 (1), 10-21.

Kusumajaya, D. K. (2011). Pengaruh Struktur Modal Dan Pertumbuhan Perusahaan Terhadap Profitabilitas Dan Nilai Peerusahaan Pada Perusahaan Manufaktur Di Bursa Efek Indonesia.

Mahardian, P. (2008). Analisis Pengaruh Rasio Car, Bopo, Npl, Nim Dan Ldr Terhadap Kinerja Keuangan Perbankan.

Maryono, B. F. (2014). Pengaruh Struktur Modal terhadap Kinerja Keuangan: Bukti Empiris Sektor Perbankan Yang Terdaftar di Bursa Efek Indonesia Periode 2008-2012 .

Myers, M. (1984). Corporate Financing and Investment Decisions When Firms Have Information That Investors Do Not Have. Journal of Financial Economic .

Payamta, M. (1999). Evaluasi Kinerja Perusahaan Perbankan Sebelum dan
Sesudah Menjadi Perusahaan Publik Di Bursa Efek Jakarta (BEJ).

Rachmawardani, Y. (2007). Analisis Pengaruh Aspek Likuiditas, Risiko Bisnis, Profitabilitas, Dan Pertumbuhan Penjualan Terhadap Stuktur Modal Perusahaan.

Sugihen, S. G. (2003). Pengaruh Struktur Modal Terhadap Produktivitas Aktiva dan Kinerja Keuangan Serta Nilai Perusahaan Industri Manufaktur Terbuka di Indonesia.

Sumarta, Y. (2000). Evaluasi Kinerja Perusahaan Perbankan Yang Terdaftar Di Bursa Efek Indonesia Dan Thailand.

Zimmerman. (1996). Factors Influencing Community Bank Performance in California. 